\title{
The Prospects of Utilizing \\ the Modified Sorption Material \\ to Intensify Purification of Waste Water \\ from Electroplating Production
}

Tatiana A. Kurilina, Olga G. Dubrovskaya*, Vladimir A. Kulagin, Anatoly I. Matyushenko and Anastasiya G. Bobrik

Siberian Federal University 79 Svobodny, Krasnoyarsk, 660041, Russia

Received 08.02.2019, received in revised form 15.02.2019, accepted 20.02.2019

One of the sources of environmental pollution with hazardous substances, primarily heavy metals, is the electroplating industry. The prevention of pollution of water bodies with wastewater containing heavy metal ions is closely related to reducing the consumption of fresh water for the technological needs of production and to reducing the amount of effluent. One of the solutions to this problem is to create low-waste and waste-free environmentally safe technological processes of wastewater treatment using treated effluents in the recirculation system, which reduces the negative impact on the environment. The results of studying the sorption properties of the natural modified mineral Akdolit-Gran prove a high efficiency of this sorption filling when conditioning electroplating shop effluents contaminated with a complex of heavy metals. Taking into account a relatively low cost of this natural mineral, Akdolit-Gran has the advantages in terms of its economic feasibility, plus the high degree of extraction of metals using this sorbent together with its low consumption allows designing recirculation systems for industrial enterprises meeting the requirements for physical and chemical parameters of service water.

Keywords: sorption neutralization, heavy metal ions, modified sorbent, dolomite rocks.

Citation: Kurilina T.A., Dubrovskaya O.G., Kulagin V.A., Matyushenko A.I., Bobrik A.G. The prospects of utilizing the modified sorption material to intensify purification of waste water from electroplating production, J. Sib. Fed. Univ. Eng. technol., 2019, 12(2), 182-191. DOI: 10.17516/1999-494X-0127.

(C) Siberian Federal University. All rights reserved

This work is licensed under a Creative Commons Attribution-NonCommercial 4.0 International License (CC BY-NC 4.0).

* Corresponding author E-mail address: dubrovskayaolga@mail.ru 


\title{
Перспективы использования
}

\section{модифицированного сорбционного материала \\ для интенсификации очистки воды \\ электропромышленного производства}

\author{
Т.А. Курилина, О.Г. Дубровская, \\ В.А. Кулагин, А.И. Матюшенко, А.Г. Бобрик \\ Сибирский федеральный университет \\ Россия, 660041, Красноярск, пр. Свободный, 79
}

\begin{abstract}
Одним из источников загрязнения окружающей среды опасными веществами, прежде всего тяжельми металлами, является гальваническая промышленность. Предотвращение загрязнения водоемов сточными водами, содержащими ионы тяжелых металлов, тесно связано с сокращением потребления пресной воды на технологические нужды производства и с уменьшением количества сточных вод. Одним из решений этой проблемы является создание малоотходных и безотходных экологически безопасных технологических процессов очистки сточных вод с использованием очищенных стоков в рециркуляционной системе, что снижает негативное воздействие на окружающую среду. Результаты изучения сорбционных свойств природного модифицированного минерала акдолит-гран доказывают высокую эффективность этого сорбционного наполнения при кондиционировании цеехов гальванического производства, загрязненных комплексом тяжелых металлов. За счет относительно низкой стоимости акдолит-гран обладает преимуществами с точки зрения его экономической целесообразности, плюс высокая степень извлечения металлов с использованием этого сорбента вместе с его низким расходом позволяет создавать системы рециркуляции для промышленных предприятий, отвечающие требованиям к физико-химическим показателям технической воды.
\end{abstract}

Ключевые слова: сорбиионная нейтрализация, ионы тяжелых металлов, модифицированный сорбент, доломитовые породы.

\section{Current state of the problem}

Sorption extraction of metals is one of the most effective methods for cleaning effluent of electroplating, its effectiveness is $80-95 \%$ depending on the sorbent used. The sorption technique of wastewater treatment using natural sorbents has been known for a long time, however, there is a large class of natural sorbents minerals which, have not been widely used due to the lack of knowledge [1-6]. Meanwhile, their advanced sorption properties, low cost, and natural abundance make them an economically feasible raw material in industrial wastewater treatment technologies. Natural materials, as a rule, are most preferable as sorption filling in terms of environmental and economic expediency. However, to increase the sorption activity and sorption capacity, the original natural materials need to be modified. The methods of modifying and activating natural sorbents include heat treatment, acid or alkaline exposure. Activation and enhancement of the sorption properties of natural materials allow obtaining highly efficient fillings with desired sorption properties and a certain selectivity.

Currently, taking into account the growing need for recirculation systems of treated industrial wastewater, searching for effective and economically-viable natural sorbents to intensify effluent treatment is an immediate problem $[8,9]$. 


\section{Research methods}

This paper studies the sorption method for removal of a complex of heavy metals, for example, $\mathrm{Cu}$ (II); Ni (II) and $\mathrm{Zn}$ (II), from aqueous solutions with a modified sorbent which bases on dolomite raw materials. This sorbent, Akdolit Kesselburger Pelm Gran CM3 (Akdolit-Gran) is produced in Germany and is widely used in Europe and the European part of Russia.

The sorbent material is thermally activated and modified by calcining the natural mineral. Calcination contributes to loosening of the rock with the formation of structures with greater porosity and specific surface [10,11]. The approximate chemical composition of Akdolit-Gran: calcium carbonate $\mathrm{CaCO}_{3}-68.9 \%$; calcium oxide $\mathrm{CaO}-1.4 \%$; magnesium oxide $\mathrm{MgO}-25.4 \%$; magnesium carbonate $\mathrm{MgCO}_{3}-0.6 \%$; iron oxide $\mathrm{Fe}_{2} \mathrm{O}_{3}-0.6 \%$; aluminum oxide $\mathrm{Al}_{2} \mathrm{O}_{3}-2.7 \%$; silicon oxide $\mathrm{SiO}_{2}-$ $0.3 \%$; water $\mathrm{H}_{2} \mathrm{O}-2.7 \%$. The percentages of the substances obtained on the basis of a regular physical and chemical testing and are the average statistical values.

\section{Research results}

The objective was to study the physical and chemical and sorption properties of AkdolitGran.

To carry out the sorption in the laboratory, we used the method of variable sorbent weights and constant volumes of the simulated solution with the initial ion concentration: $\mathrm{Cu}$ (II) $=60 \mathrm{mg} / \mathrm{dm}^{3} ; \mathrm{Ni}$ (II) $=15 \mathrm{mg} / \mathrm{dm}^{3} ; \mathrm{Zn}$ (II) $=20 \mathrm{mg} / \mathrm{dm}^{3}$. These concentrations are most common in the electroplating industry wastewater. The residual concentration was determined on an ICAP-6500 Inductively Coupled Plasma Atomic Emission Spectrometer.

The sorbent mineralogical composition was determined based on the data from X-ray crystallography carried out on a DRON-3 diffractometer, in $\mathrm{Cu}-\mathrm{K}_{\alpha}$ radiation.

The analysis of the diffractogram indicates that the main phase in the sorbent is calcite $\mathrm{CaCO}_{3}$ $(\mathrm{d}=0.38 ; 0.30 ; 0.23 ; 0.19 ; 0.18 \AA)$; besides, there is a rather significant amount of magnesium oxide $\mathrm{MgO}$

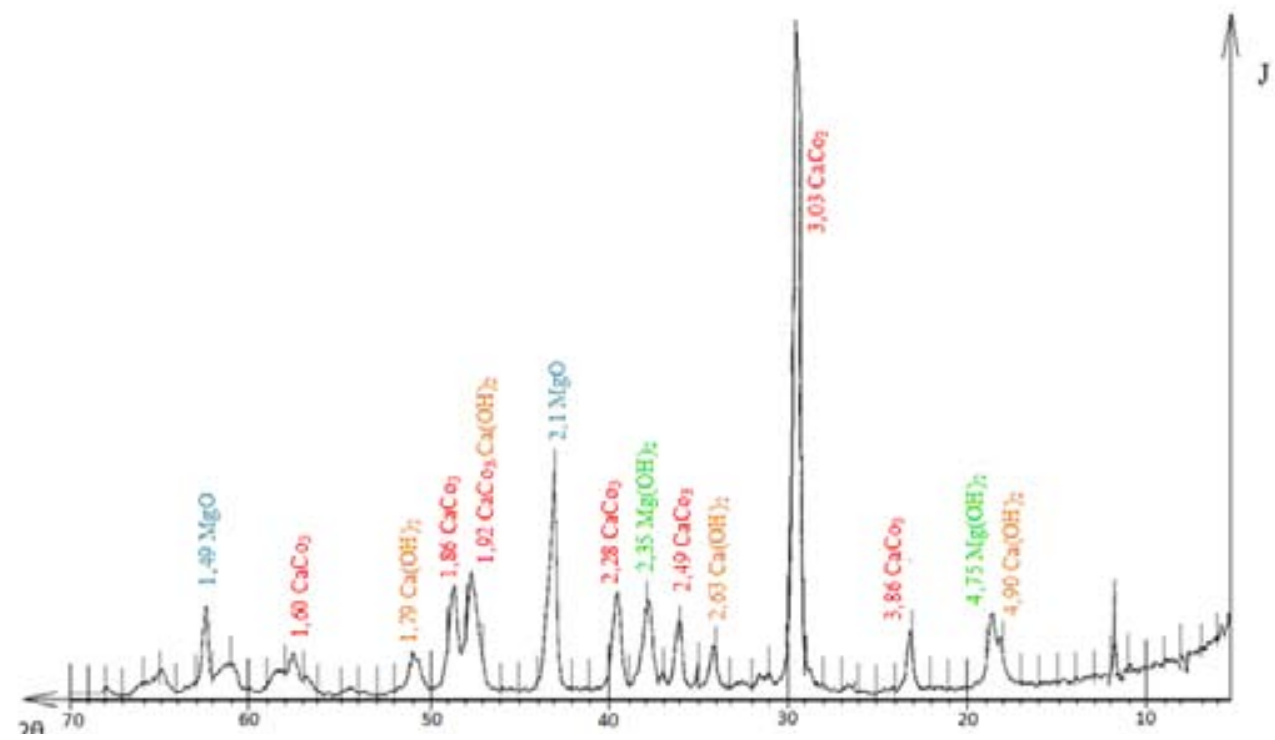

Fig. 1. The diffractogram of Akdolit-Gran 
$(\mathrm{d}=0.21 ; 0.15 \AA)$. Low-intensity diffraction maxima correspond to magnesium hydroxide $\mathrm{Mg}(\mathrm{OH})_{2}$ $(\mathrm{d}=0.21 ; 0.15 \AA)$ and calcium hydroxide $\mathrm{Ca}(\mathrm{OH})_{2}(\mathrm{~d}=0.49 ; 0.26 \AA)$ resulting from hydrolysis oxides of magnesium and calcium contained in the sorbent. The remaining substances specified in the technical documentation for the sorbent $\left(\mathrm{MgCO}_{3}, \mathrm{Fe}_{2} \mathrm{O}_{3}, \mathrm{Al}_{2} \mathrm{O}_{3}\right.$, and $\left.\mathrm{SiO}_{3}\right)$ were not detected due to their low concentration. For a more detailed study of the sorbent sample, we carried out a thermal analysis on an STA 449 F1 (simultaneous thermal analyzer), by NETZSCH (Germany), in an argon medium. The thermogram of the Akdolit-Gran sample is shown in Fig. 2. The number, shape and position of various exothermic and endothermic peaks relative to the temperature scale were used to qualitatively identify the sample being studied.

The sample thermal analysis data show 4 endo-effects on the DSC. A minor endo-effect at $109^{\circ} \mathrm{C}$ refers to removal of the adsorbed water, the endo-effect at $430^{\circ} \mathrm{C}$ is caused by dehydration of $\mathrm{Mg}(\mathrm{OH})_{2}$ :

$$
\mathrm{Mg}(\mathrm{OH})_{2} \rightarrow \mathrm{MgO}+\mathrm{H}_{2} \mathrm{O}
$$

meanwhile, the sample mass, as shown by the TC, decreases $\sim 5.59 \%$ in this temperature range, the compound of $\mathrm{Mg}(\mathrm{OH})_{2}$ in the sample is $\sim 18 \%$, it is followed by the endo-effect at $476^{\circ}$ which is caused by dehydration of $\mathrm{Ca}(\mathrm{OH})_{2}$ :

$$
\mathrm{Ca}(\mathrm{OH})_{2} \rightarrow \mathrm{CaO}+\mathrm{H}_{2} \mathrm{O}
$$

the mass decreases by $0.59 \%$; a large endo-effect is observed at $\mathrm{t}=844^{\circ} \mathrm{C}$, which is related to calcite decarbonization, i.e. calcite $\mathrm{CaCO}_{3}$ decomposes with formation of $\mathrm{CO}_{2}$ :

$$
\mathrm{CaCO}_{3} \rightarrow \mathrm{CaO}+\mathrm{CO}_{2} \uparrow ;
$$

the sample mass is reduced by approximately $27 \%$, the content of $\mathrm{CaCO}_{3}$ in the sample is $61.4 \%$ according to the thermogram.

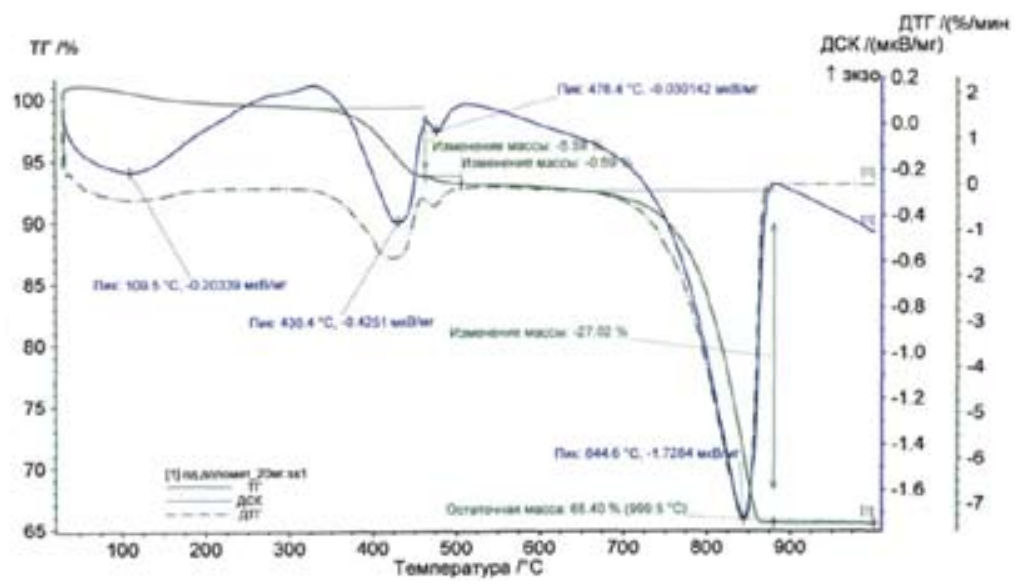

Fig. 2. Thermogram of Akdolit-Gran: DTC is a differential thermogravimetric curve (shows the rate of change of mass, this is the first derivative of TC), TC is a thermogravimetric curve which shows the change of mass during heating (the mass increases or decreases), DSC is a differential scanning curve (DSC and DTA show endo- and exo-effects occurring during heating, DTA is an analysis from one point, DSC is an analysis from the whole surface) 
According to the data of differential-thermal and X-ray phase analyses of the sorbent, we can conclude that during heat treatment, chemical transformations also take place, which results in the formation of calcium carbonate and magnesium oxide.

We determined the technical characteristics of the sorbent abiding by the standard techniques (see Table 1).

The dose values of the proposed sorption material are found experimentally and given in Table 2 .

The experiment performed (see Table 2) showed that the cleaning effect with the use of AkdolitGran sharply reduces in an acidic medium. The reason for this can be a change in the colloid-chemical properties of the sorbent, the isoelectric point of which corresponds to $\mathrm{pH}=5.4$ approximately, therefore, when the $\mathrm{pH}$ is below this value, the reaction centres on the sorbent granules are deactivated,

Table 1. Technical characteristics of the sorbent

\begin{tabular}{|l|c|}
\hline Total pore volume, $\mathrm{V}_{\Sigma}(\mathrm{cm} / \mathrm{g})$ & 0.103 \\
\hline Bulk density, $\rho_{\mathrm{b}}\left(\mathrm{g} / \mathrm{cm}^{3}\right)$ & 1.15 \\
\hline Real density $\rho\left(\mathrm{g} / \mathrm{cm}^{3}\right)$ & 2.37 \\
\hline Average density $\rho_{0}\left(\mathrm{~g} / \mathrm{cm}^{3}\right)$ & 2.26 \\
\hline Porosity $\mathrm{P}(\%)$ & 4.64 \\
\hline Water absorption $\mathrm{W}(\%)$ & 10.3 \\
\hline
\end{tabular}

Table 2. The experimental results

\begin{tabular}{|c|c|c|c|c|c|}
\hline No. & $\begin{array}{l}\text { Dsb - dose of the } \\
\text { sorbent } \mathrm{mg} / \mathrm{dm}^{3}\end{array}$ & $\mathrm{pH} 0$ & $\begin{array}{c}\text { Residual } \\
\text { concentration } \\
\text { of } \mathrm{Cu}^{2+}, \mathrm{mg} / \mathrm{dm}^{3}\end{array}$ & $\begin{array}{c}\text { Residual } \\
\text { concentration } \\
\text { of } \mathrm{Ni}^{2+}, \mathrm{mg} / \mathrm{dm}^{3}\end{array}$ & $\begin{array}{c}\text { Residual } \\
\text { concentration } \\
\text { of } \mathrm{Zn}^{2+}, \mathrm{mg} / \mathrm{dm}^{3}\end{array}$ \\
\hline 1 & 1.0 & 3.0 & 9.736 & 6.128 & 4.902 \\
\hline 2 & 1.0 & 7.0 & 0.123 & 1.495 & 1.295 \\
\hline 3 & 1.0 & 9.0 & 1.131 & 0.183 & 0.0152 \\
\hline 4 & 1.0 & 11.0 & 1.268 & 0.199 & 0.0098 \\
\hline 5 & 1.2 & 3.0 & 8.131 & 6.103 & 3.663 \\
\hline 6 & 1.2 & 7.0 & 0.305 & 0.923 & 1.306 \\
\hline 7 & 1.2 & 9.0 & 0.192 & 0.163 & 0.0081 \\
\hline 8 & 1.2 & 11.0 & 0.193 & 0.198 & 0.0093 \\
\hline 9 & 1.6 & 3.0 & 7.961 & 5.932 & 3.569 \\
\hline 10 & 1.6 & 7.0 & 0.129 & 0.138 & 1.0061 \\
\hline 11 & 1.6 & 9.0 & 0.109 & 0.162 & 0.0062 \\
\hline 12 & 1.6 & 11.0 & 0.203 & 0.204 & 0.0161 \\
\hline 13 & 2.0 & 3.0 & 7.805 & 5.862 & 4.998 \\
\hline 14 & 2.0 & 7.0 & 0.905 & 0.132 & 1.0092 \\
\hline 15 & 2.0 & 9.0 & 0.129 & 0.193 & 0.0103 \\
\hline 16 & 2.0 & 11.0 & 0.151 & 0.235 & 0.0198 \\
\hline
\end{tabular}


the bimolecular attraction of the binary layer decreases, which causes electrostatic repulsion of metal ions from the sorbent surface.

When analysing the sorption parameters of the studied Akdolit-Gran, we determined the following: $A_{\mathrm{sb}}$ - absorbing capacity of the sorbent, $\mathrm{k}_{\mathrm{d}}$ - a coefficient of metal distribution between the simulated solution and the sorbent, $\mathrm{k}_{\mathrm{sb}}$ - a preset degree of the sorbent capacity exhaustion, $\mathrm{R}-\mathrm{a}$ degree of metal extraction from the solution, $\mathrm{D}_{\mathrm{sb}}-$ dose of the sorbent [12-14]. The calculus results are given in Tables 3-5.

The sorption capacity of Akdolit - Gran varies in respect of the studied materials. Evaluation of the sorbent efficiency for extraction of metals from aqueous solutions using a specific sorption capacity

Table 3. The absorbing capacity of Akdolit-Gran (Asb, mg/g)

\begin{tabular}{|c|c|c|c|c|}
\hline Item & $\begin{array}{c}\text { Dsb-dose of Akdolit }- \\
\text { Gran, } \mathrm{mg} / \mathrm{dm}^{3}\end{array}$ & $\mathrm{Cu}^{2+}$ & $\mathrm{Ni}^{2+}$ & $\mathrm{Zn}^{2+}$ \\
\hline 1 & 1 & 57.74 & 13.01 & 19.87 \\
\hline 2 & 1.2 & 48.16 & 11.71 & 16.37 \\
\hline 3 & 1.4 & 41.28 & 10.27 & 14.14 \\
\hline 4 & 1.6 & 36.76 & 8.63 & 12.35 \\
\hline 5 & 1.8 & 32.26 & 7.26 & 10.54 \\
\hline 6 & 2.0 & 28.15 & 6.37 & 9.19 \\
\hline
\end{tabular}

Table 4. The coefficient of metal distribution between the simulated solution and the sorbent (kd, g/dm $\left.{ }^{3}\right)$

\begin{tabular}{|c|c|c|c|c|}
\hline Item & $\begin{array}{c}\text { Dsb-dose of Akdolit }- \\
\text { Gran, } \mathrm{g} / \mathrm{dm}^{3}\end{array}$ & $\mathrm{Cu}^{2+}$ & $\mathrm{Ni}^{2+}$ & $\mathrm{Zn}^{2+}$ \\
\hline 1 & 1 & 25.59 & 6.55 & 155.23 \\
\hline 2 & 1.2 & 21.81 & 12.48 & 45.98 \\
\hline 3 & 1.4 & 18.68 & 16.48 & 67.98 \\
\hline 4 & 1.6 & 31.20 & 7.29 & 52.55 \\
\hline 5 & 1.8 & 16.69 & 3.77 & 10.28 \\
\hline 6 & 2.0 & 7.61 & 2.83 & 5.64 \\
\hline
\end{tabular}

Table 5. The degree of metal extraction from the solutions (R, \%)

\begin{tabular}{|c|c|c|c|c|}
\hline Item & $\begin{array}{c}\text { Dsb - dose of Akdolit - } \\
\text { Gran, } \mathrm{g} / \mathrm{dm}^{3}\end{array}$ & $\mathrm{Cu}^{2+}$ & $\mathrm{Ni}^{2+}$ & $\mathrm{Zn}^{2+}$ \\
\hline 1 & 1 & 96.24 & 86.76 & 99.36 \\
\hline 2 & 1.2 & 96.32 & 93.75 & 98.22 \\
\hline 3 & 1.4 & 96.32 & 95.85 & 98.96 \\
\hline 4 & 1.6 & 98.03 & 92.11 & 98.92 \\
\hline 5 & 1.8 & 96.78 & 87.16 & 94.87 \\
\hline 6 & 2.0 & 93.83 & 84.94 & 91.86 \\
\hline
\end{tabular}


can lead to erroneous conclusions. Thus, evaluation of the efficiency of immobilization of heavy metals using the values of the sorption capacity gives the following row of sorption: $\mathrm{Cu}^{2+}>\mathrm{Zn}^{2+}>\mathrm{Ni}^{2+}$, and by means of the metals distribution coefficient and the degree of extraction of metals we see the following sequence: $\mathrm{Zn}^{2+}>\mathrm{Cu}^{2+}>\mathrm{Ni}^{2+}$. This is due to the fact that the sorption capacity depends on the mass of the sample taken.

Ionic potential, i.e. a surface charge of the ion can be used to assess a surface dissociation degree.

The ionization potential is determined by the formula

$$
\mathrm{IP}=\frac{n \cdot e}{r}
$$

where $n$ is a number of electrons; $e$ is an electron charge.

$\mathrm{Cu}^{2+}, \mathrm{Zn}^{2+}$ and $\mathrm{Ni}^{2+}$ have got 2 electrons, and the electron charge is 1.602 . There is a dependence [12] stating that the larger the radius of the ion is, the smaller the ionization potential will be. The radius of the atom for $\mathrm{Cu}^{2+}$ is $1.278 \dot{A}$, the radius of the $\mathrm{Zn}^{2+}$ atom is $1.333 \dot{A}$, and the radius of the for the $\mathrm{Ni}^{2+}$ atom is $1.246 \dot{A}$; and according to this feature, the studied metals arrange in a row $\mathrm{Zn}^{2+}>\mathrm{Cu}^{2+}$ $>\mathrm{Ni}^{2+}$, which corresponds to the experimental findings.

Table 6 shows the results of the study and calculation of the kinetics of the sorption process of copper (II), nickel (II) and zinc (II) ions.

Which also gives the following sequence of distribution of metals in the extraction rate:

$$
\mathrm{Zn}^{2+}>\mathrm{Cu}^{2+}>\mathrm{Ni}^{2+}
$$

As the sorption process is exothermic, when temperature increases, the capacity of the sorbent with respect to metals decreases $[15,16]$, which is confirmed by the results (Table 7).

The phenomena of physical and chemical sorption clearly differ in some rare cases. There usually occur intermediate variants when the bulk adsorbed substance is relatively weakly bound, and only a small part of it binds firmly [17-19]. When the temperature is rising, an increase in chemical adsorption begins blocking a fall in physical sorption, starting from a certain temperature; therefore, the temperature dependence of sorption has a clear minimum in this case (Table 8).

These experimental data were used to develop a project to restore wastewater treatment facilities using the proposed sorption material.

Table 6. The results of the calculation of the sorption rate constant, depending on the dose of the sorbent

\begin{tabular}{|c|c|c|c|}
\hline \multirow{2}{*}{$\begin{array}{c}\text { Dsb-dose } \\
\text { of the sorbent } \mathrm{mg} / \mathrm{dm}^{3}\end{array}$} & \multicolumn{3}{|c|}{$\mathrm{K}, \mathrm{sec}^{-1}$} \\
\cline { 2 - 4 } & $\mathrm{Cu}^{2+}$ & $\mathrm{Ni}^{2+}$ & $\mathrm{Zn}^{2+}$ \\
\hline 1 & 3.28 & 2.02 & 5.05 \\
\hline 1.2 & 3.3 & 2.77 & 4.02 \\
\hline 1.4 & 3.3 & 3.18 & 4.44 \\
\hline 1.6 & 3.9 & 2.54 & 2.97 \\
\hline 1.8 & 3.4 & 2.05 & 2.51 \\
\hline 2.0 & 2.78 & 1.89 & \\
\hline
\end{tabular}


Table 7. The dependence of the sorption capacity $\left(\mathrm{A}_{\mathrm{sb}}, \mathrm{mg} / \mathrm{g}\right)$ and the solution temperature, $\mathrm{mg} / \mathrm{g}$

\begin{tabular}{|c|c|c|c|c|}
\hline \multirow{2}{*}{ Item } & \multirow{2}{*}{ Temperature $^{\circ} \mathrm{C}$} & \multicolumn{3}{|c|}{$\mathrm{A}_{\mathrm{sb}}, \mathrm{mg} / \mathrm{g}$} \\
\cline { 3 - 5 } & & $\mathrm{Cu}(\mathrm{II})$ & $\mathrm{Ni}(\mathrm{II})$ & $\mathrm{Zn}(\mathrm{II})$ \\
\hline 1 & 11.5 & 41.78 & 10.22 & 14.06 \\
\hline 2 & 17.0 & 42.75 & 10.59 & 14.28 \\
\hline 3 & 25.0 & 42.76 & 10.63 & 14.26 \\
\hline 4 & 33.0 & 42.76 & 10.67 & 14.27 \\
\hline 5 & 38.5 & 42.77 & 10.70 & 14.22 \\
\hline 6 & 60.0 & 42.76 & 10.62 & 14.20 \\
\hline 7 & 70.5 & 42.71 & 10.61 & 14.14 \\
\hline 8 & 80.0 & 42.71 & 10.57 & \\
\hline
\end{tabular}

Table 8. The calculation results for the dependence of the residual concentration and the temperature of the aquatic medium

\begin{tabular}{|c|c|c|c|}
\hline \multirow{2}{*}{ Temperature ${ }^{\circ} \mathrm{C}$} & \multicolumn{3}{|c|}{$\mathrm{C}_{\text {res. }}$} \\
\cline { 2 - 4 } & $\mathrm{Cu}(\mathrm{II})$ & $\mathrm{Ni}(\mathrm{II})$ & $\mathrm{Zn}(\mathrm{II})$ \\
\hline 11.5 & 2.201 & 0.689 & 0.308 \\
\hline 17.0 & 0.151 & 0.161 & 0.005 \\
\hline 25.0 & 0.128 & 0.112 & 0.031 \\
\hline 33.0 & 0.131 & 0.056 & 0.0053 \\
\hline 38.5 & 0.121 & 0.013 & 0.0101 \\
\hline 60.0 & 0.136 & 0.128 & 0.0805 \\
\hline 70.5 & 0.207 & 0.146 & 0.108 \\
\hline 80.0 & 0.210 & 0.202 & 0.196 \\
\hline
\end{tabular}

\section{Conclusion}

The results of studying the sorption properties of the natural modified mineral Akdolit-Gran prove a high efficiency of this sorption filling when conditioning electroplating shop effluents contaminated with a complex of heavy metals. Taking into account a relatively low cost of this natural mineral, Akdolit-Gran has the advantages in terms of its economic feasibility, plus the high degree of extraction of metals using this sorbent together with its low consumption allows designing recirculation systems for industrial enterprises meeting the requirements for physical and chemical parameters of service water.

Based on these results, we can conclude the following:

1. It is reasonable to use this sorbent as a potential ion exchange sorbent to treat the electroplating effluents since calcium and magnesium ions function as the exchangeable ions.

2. The cation sorption occurs both via the mechanism of ion exchange (exchange with cations in inter-packet spaces and via formation of complex compounds. 
3. The optimal amount of Akdolit-Gran is about $1.4-1.6 \mathrm{gr} / \mathrm{dm}^{3}$ for solutions with an initial concentration: $\mathrm{Cu}(\mathrm{II})=60 \mathrm{gr} / \mathrm{dm}^{3} ; \mathrm{Ni}(\mathrm{II})=15 \mathrm{gr} / \mathrm{dm}^{3} ; \mathrm{Zn}(\mathrm{II})=20 \mathrm{gr} / \mathrm{dm}^{3}$, the temperature range is set within $33,0-38,0^{\circ} \mathrm{C}$.

4. The effect of cleaning the effluent from heavy metals using Akdolit-Gran is $93-98 \%$ in an alkaline environment, but it sharply decreases in an acidic environment.

\section{Acknowledgment}

The reported study was funded by RFBR and the government of Krasnoyarsk region according to the research projects №№ 18-48-242001, 18-41-242004, 18-41-242008

\section{References}

[1] Bek R.Yu. The impact of electroplating industry on the environment and ways to reduce the damage. Analytical review of the Academy of Sciences of the USSR. Siberian Branch. Institute of Solid State Chemistry and Mineral Processing; State Public Scientific and Engineering Library. Novosibirsk, 1991. 96 p. (in Russian)

[2] Tarasevich Yu.I. Natural sorbents in water purification processes. Kiev. Naukova Dumka. 1981. 206 p. (in Russian)

[3] Alykov N.M., Pavlova A.V., Nguen K.Kh., Abuova G.B., Utyubaeva N.V. A new sorbent for purification of water from ions of toxic metals. Natural Sciences. Journal of Fundamental and Applied Research. 2009. No. 4 (29). Pp. 150-158.

[4] Dzhigola L.A., Simakova Yu.M., Rubleva A.V., Nikitina O.V., Urazalieva A.K. The study of sorption on moulding boxes and diffusion of heavy metal ions in clays. Natural Sciences. Journal of Fundamental and Applied Research. 2009. No. 4(29). Pp. 175-180.

[5] Rogaleva E.V., Vorontsova N.V., Pilipenko A.I., Ganyaev V.P. Purification of natural water from heavy metal ions by sorption and ozonation. Proceedings of Higher Educational Institutions. Oil and Gas. 2008. No. 2. Pp. 102-104.

[6] Khuramshina I.Z., Nikiforov A.F., Migalatiy E.V., Baranov O.Yu. The interaction of copper (II) with a natural mineral sorbent in the processes of aqueous solutions purification. Water purification. Water treatment. Water supply. 2008. 2(74). Pp. 22-26

[7] Nikiforov A.Yu. The use of natural dolomite and its thermally modified forms to purify wastewater from heavy metal cations. Proceedings of Higher Educational Institutions. Chemistry and Chemical Engineering. 1999. No. 4.

[8] Nadeem R., Hanif M., Shaheen F. et al. Physical and chemical modification of distillery sludge for $\mathrm{Pb}$ (II) biosorption. J. Hazard. Matter. 2008. V. 150. P. 335-342.

[9] Padmavathy V. Biosorption of nickel (II) ions by baker's yeast: Kinetic, thermodynamic and desorption studies. Bioresource. Technol. 2008. V. 99. P. 3100-3109.

[10] Godymchuk A.Yu., Reshetova A.A. Studying the extraction of heavy metals on natural minerals (electronic source). Bulletin of the Department of Earth Sciences RAS (Electronic Scientific Information Journal) No. 1(21) 2003 URL: http://www.scgis.ru/russian/cp1251/h_dgggms/1-2003/ informbul-1/hydroterm-17.pdf

[11] Niyazi F.F., Maltseva V.S., Sazonova A.V. The kinetic patterns of sorption of iron (II, III) ions by modified carbonate rocks. Vestnik South-West State University. Series «Physics and Chemistry». 2012. No. 1. Pp. 40-47. (in Russian) 
[12] Kulagin V.A., Kurilina T.A., Dubrovskaya O.G., Matyushenko A.I. Using the akdolit-gran modification for sorption treatment of wastewater of electroplatin]. Water treatmen. 2018. No. 10. Pp. $12-27$.

[13] Domracheva V.A. Extraction of metals from wastewater and anthropogenic formations. Publishing house of Irkutsk State Technical University. Irkutsk. 2006. 151 p. (in Russian)

[14] Levchenko S.I. Physical and colloidal chemistry. Rostov-on-Don. 2004. 77 p. http://www. physchem.chimfak.rsu.ru/ (in Russian)

[15] Bikulova V.Zh., Latypova F.M., Mukhametdinova L.Kh. Adsorption purification of industrial wastewater from zinc ions. Water, Chemistry and Ecology. 2013. No. 3.

[16] Orazova S.S., Belov V.M., Evstigneev V.V. Efficiency of using natural sorbents of Eastern Kazakhstan in water purification from heavy metal ions $\mathrm{Cu}^{2+}$ Vestnik of Tomsk Polytechnic University. 2007. No. 2, vol. 311. (in Russian)

[17] Andryshev A.K., Kolpakov V.P., Lopukhov Yu.I., Daumova G.K. The effective purification technology for chromium-containing wastewater using modified sorbents. Water purification. Water treatment. Water supply. 2014. No. 9. (in Russian)

[18] Shcherbakov A.V. Sewage treatment to purify from heavy metal salts. Energy Efficiency and Water Treatment. 2013. No. 3. (in Russian)

[19] Dubrovskaya O.G., Eldarzade E.A., Andrunyak I.V. Research and production of sorption materials based on the technology of recycling waste from the heat and power industry. Safety and Monitoring of Anthropogenic and Natural Systems: Materials of International Scientific Conference, Krasnoyarsk, September 18-21, 2018; ed.-in-chief V.V. Moskvichev. Krasnoyarsk: Publishing House of Siberian Federal University. 2018. (in Russian) 